Pedagogy and Psychology of Sport, Vol. 2 / No 2, 2016

Banaczkowska Alicja, Eksterowicz Jerzy, Zukow Walery, p. 16-29

Received: 01.05.2016. Revised 12.07.2016. Accepted: 31.08.2016.

DOI:http://dx.doi.org/10.12775/PPS.2016.008

Original Text published (C) The Author (s) 2016.

Banaczkowska Alicja, Eksterowicz Jerzy, Zukow Walery. Kuchnia tradycyjna jako czynnik wpływający na rozwój turystyki regionu na przykladzie Krajny = Traditional Kitchen as a factor in the development of tourism in the region as an example Krajna. Journal of Education, Health and Sport. 2016;6(2):47-63. eISSN 2391-8306. DOI http://dx.doi.org/10.5281/zenodo.45767 http://ojs.ukw.edu.pl/index.php/johs/article/view/3377

\title{
Traditional Kitchen as a factor in the development of tourism in the region as an example Krajna
}

\section{Kuchnia tradycyjna jako czynnik wpływający na rozwój turystyki regionu na przykładzie Krajny}

\author{
Alicja Banaczkowska ${ }^{1}$, Jerzy Eksterowicz ${ }^{2}$, Walery Zukow ${ }^{2}$ \\ ${ }^{1}$ Wyższa Szkoła Gospodarki, Bydgoszcz \\ ${ }^{2}$ Uniwersytet Kazimierza Wielkiego, Bydgoszcz
}

Keywords: traditional kitchen, tourism, Krajna

Słowa kluczowe: kuchnia tradycyjna, turystyka, Krajna

\begin{abstract}
Introduction: This study concerns the impact of values of the local traditional cuisine on the development of tourism. In this perspective, the region has been designated a cultural Krajny called. land border. It is taken to discuss this issue because of the need and obligation at the same time learn from the cultural heritage for the benefit of the development of society. An example of this giving impetus to the development of tourism may be the use of flavors and aromas of the old Polish cuisine as a tourist attracting tourists.

Aim: The aim of the research is to determine the impact of cultural and ethnic values of the region (regional cuisine) to develop a tourism function in the region for example Krajna. The area was chosen because of the interest in the subject of promoting elements of folk culture and the feasibility of the topic including their competence, time and technical means. Not without significance is also co-author of his own experience, which initially was the recipient of media folk art, and also the animator.

Problems and hypotheses: According to the research problem (Frakfort-Nachmias 2001) is an impressive intellectual stimulus response in the form of research. The research problem can be established as an affirmative sentence or questioning, and the same formulation of the problem is to determine the questions that have either no response, or it is not sufficiently precise. It is formulated using specific terms that reflect the empirical phenomena. The hypothesis of the research is preliminary answer to the stated problem, giving up empirically (to be verified in the course of research).In this paper, the following research problems and hypotheses:

The root problem:

1. What is the degree of impact on the traditional increase in interest in the region by both potential tourists and locals?
\end{abstract}


Specific problems:

1. What is the level of interest in regional cuisine among the inhabitants of the provinces mainly Wielkopolska, Pomerania and Kujawy-Pomerania (on grounds of administrative Krajna)?

2. What is the knowledge of traditional Polish dishes and regional authorities?

3. Is the public awareness for the concept tavern-style restaurant offering regional food?

4. Is Krajna as a cultural region is recognizable?

5. Are regional cuisine is attractive?

6. Does the attractiveness of regional cuisine can be a decisive factor in choosing a vacation destination or travel?

7. Do the methods promote regional produce sufficient?

Main hypothesis:

1. It is assumed that the degree of impact on the traditional increase in interest in the region by both potential tourists and locals is high.

Hypotheses particulars:

1. It is assumed that the level of interest in regional cuisine among the inhabitants of the provinces of Wielkopolska, Pomerania and Kujawy-Pomerania (on grounds of administrative Krajny) is at a medium level.

2. It is assumed that knowledge of traditional Polish dishes and regional is at a medium level.

3. It is assumed that in the public consciousness, moderate operating concept restaurant type inn offering regional food.

4. It is assumed that Krajna as a cultural region is recognizable.

5. It is assumed that the regional cuisine is attractive.

6. It is assumed that the attractiveness of regional cuisine can be a decisive factor

the choice of vacation destination or travel to a high degree.

7. It is assumed that the methods of promoting regional products are insufficient.

Methods, techniques and tools of measurement

The research methods used in this study are: diagnostic survey,

and as the main technique adopted surveys, a questionnaire consisting of

with 6 questions, most of them closed was completed online by 117 respondents attempt. The research was to measure the level of knowledge about regional dishes and interest Krajná as a cultural region. Due to the high rating the attractiveness of traditional dishes of regional cuisine, it was decided to confirm the point of the survey with the help of techniques to support the research process, which are observation and interview-free terrain. Observations and interview free- terrain, which were to some extent the consumer survey, conducted on a sample of 52 people taken care of is that this attempt was represented by people of all ages living in the countryside and in the city.

Research Results and Discussion

Characteristics of the study group / trials

Surveys were conducted on a sample of 117 people with simple random sampling, in the age group 19-30 years. These people are residents of the provinces of Wielkopolskie, Kujawsko-Pomorskie and Pomorskie. The respondents came from both rural and urban areas.

verification of hypotheses

Verification carried out based on the combined results of the research showed that confirmed seven of the eight established hypotheses.

Hypothesis No. 1 assuming that the degree of impact on the traditional increase in interest in the region by both potential tourists and locals alike is high, fully confirmed the.

Hypothesis No. 2 assuming that the level of interest in regional cuisine among the inhabitants of the provinces of Wielkopolskie, Kujawsko-Pomorskie and Pomorskie is at the average level, has not confirmed the

Hypothesis 3 assuming that the knowledge of traditional Polish dishes and regional authorities is at the average level, confirmed the.

Hypothesis No. 4 assuming that in the public consciousness, moderate operating concept restaurant type inn offers regional food, a confirmed.

Hypothesis No. 5 assuming that Krajna as a cultural region is recognized, confirmed the.

Hypothesis No. 6 assuming that the regional cuisine is attractive, confirmed the. Respondents assessed the regional cuisine as particularly attractive.

Hypothesis No. 7 assuming that the attractiveness of regional cuisine can be a decisive factor in choosing a vacation destination or travel to a high degree, confirmed the.

Hypothesis No. 8 assuming that the methods of promoting regional products are not sufficient to confirmed. Conclusion

As a result of the analysis of the research were formulated following conclusions:

1. The attractiveness of dishes prepared according to traditional recipes, using natural ingredients positively influence the choice of vacation destination or travel.

2. Regional traditional cuisine is part of a highly attractive and as such can affect the development of cultural tourism, and tourism in general in the studied area. 
3. An important role in the dissemination of traditional and regional cuisine are restaurants, inns and taverns that cultivate the local tradition through the décor and regional cuisine.

4. Regional cuisine can be an excellent complement to other tourism products, in particular those related to national heritage and local cultural tourism.

\section{Streszczenie}

Niniejsze opracowanie dotyczy wpływu walorów lokalnej kuchni tradycyjnej na rozwój turystyki. W tym ujęciu wskazany został region kulturowy Krajny, tzw. ziemi pogranicza. Podjęto się omówienia powyższego zagadnienia ze względu na $\mathrm{p}$ otrzebę i jednocześnie obowiązek czerpania $\mathrm{z}$ dziedzictwa kulturowego, $\mathrm{z}$ pożytkiem dla rozwoju społeczeństwa. Przykładem takiego działania dającego impuls dla rozwoju turystyki może być wykorzystanie smaków i aromatów dawnej kuchni polskiej, jako atrakcji przyciągającej turystów.

Cel pracy:Celem przeprowadzanych badań jest określenie wpływu kulturowo-etnicznych walorów regionu (kuchnia regionalna) na rozwijanie się funkcji turystycznej w danym regionie na przykładzie Krajny. Obszar wybrany został z uwagi na zainteresowanie tematyką propagowania elementów kultury ludowej oraz możliwości realizacji tematu w tym posiadane kompetencje, czas i środki techniczne. Nie bez znaczenia są też własne doświadczenia współautorki, która początkowo była odbiorcą przekazu sztuki ludowej, a następnie także jej animatorem.

Problemy i hipotezy badawcze: Problem badawczy według ( Frakfort'a-Nachmias'a, 2001) to bodziec intelektualny wywołujący reakcję w postaci badań naukowych. Problem badawczy może być ustanowiony jako zdanie twierdzące lub pytające, a samo sformułowanie problemu polega na określeniu pytania, na które albo jeszcze nie ma odpowiedzi, albo nie jest ona dostatecznie precyzyjna. Jest formułowany za pomocą określonych pojęć, które odzwierciedlają zjawiska empiryczne. Hipoteza badawcza jest to wstępna odpowiedz na postawiony problem, dająca się sprawdzić empirycznie (należy ją zweryfikować w toku badań).

W niniejszej pracy wyodrębniono następujące problemy badawcze oraz hipotezy:

Problem główny:

1. Jaki jest stopień oddziaływania tradycyjnej kuchni na wzrost zainteresowania danym regionem zarówno przez potencjalnych turystów jak i lokalnych mieszkańców?

Problemy szczegółowe:

1. Jaki jest poziom zainteresowania kuchnią regionalną wśród mieszkańców województw: głównie wielkopolskiego, pomorskiego i kujawsko-pomorskiego (ze względu na przynależność administracyjną Krajny)?

2. Jaka jest wiedza na temat potraw staropolskich i regionalnych?

3. Czy w świadomości społecznej funkcjonuje pojęcie restauracji typu karczma oferującej regionalne jedzenie?

4. Czy Krajna jako region kulturowy jest rozpoznawalna?

5. Czy kuchnia regionalna jest atrakcyjna?

6. Czy atrakcyjność kuchni regionalnej może być czynnikiem decydującym o wyborze miejsca wypoczynku lub podróży?

7. Czy metody promocji produktów regionalnych są wystarczające? Hipoteza główna:

1. Zakłada się, że stopień oddziaływania tradycyjnej kuchni na wzrost zainteresowania danym regionem zarówno przez potencjalnych turystów jak i lokalnych mieszkańców jest wysoki.

Hipotezy szczegółowe:

1. Zakłada się, że poziom zainteresowania kuchnią regionalną wśród mieszkańców województw: wielkopolskiego, pomorskiego i kujawsko-pomorskiego (ze względu na przynależność administracyjną Krajny) jest na średnim poziomie.

2. Zakłada się, że wiedza na temat potraw staropolskich i regionalnych jest na średnim poziomie.

3. Zakłada się, że w świadomości społecznej, w stopniu umiarkowanym funkcjonuje pojęcie restauracji typu karczma oferującej regionalne jedzenie.

4. Zakłada się, że Krajna jako region kulturowy jest rozpoznawalna.

5. Zakłada się, że kuchnia regionalna jest atrakcyjna.

6. Zakłada się, że atrakcyjność kuchni regionalnej może być czynnikiem decydującym o wyborze miejsca wypoczynku lub podróży w stopniu wysokim.

7. Zakłada się, że metody promocji produktów regionalnych są niewystarczające.

Metody, techniki i narzędzia pomiaru: Zastosowane metody badawcze w niniejszym opracowaniu to: sondaż diagnostyczny, a jako główną technikę przyjęto badania ankietowe, kwestionariusz ankiety składający się z 6 pytań, w większości zamkniętych, został wypełniony online przez próbę 117 respondentów. Badania miały zmierzyć poziom wiedzy o potrawach regionalnych oraz zainteresowania Krajną jako regionem kulturowym. Z uwagi na wysoką ocenę atrakcyjności potraw tradycyjnych kuchni regionalnej, postanowiono potwierdzić dany punkt badań ankietowych przy pomocy technik wspierających proces badawczy, jakimi są obserwacja oraz wywiad swobodny-terenowy. Obserwacje i wywiad swobodny- terenowy, który stanowiły poniekąd badanie opinii konsumentów, przeprowadzono na próbie 52 osób, zadbano o to aby próba ta reprezentowała osoby w różnym wieku zamieszkujące na wsi i w mieście. Wyniki Badań i ich omówienie" Charakterystyka badanej grupy/próby 
Badania sondażowe zostały przeprowadzone na próbie 117 osób z doboru losowego prostego, w przedziale wiekowym 19-30 lat. Ludzie ci są mieszkańcami województw: wielkopolskiego, pomorskiego, kujawskopomorskiego. Badani respondenci pochodzili zarówno z obszarów wiejskich jak i miejskich.

Weryfikacja hipotez

Weryfikacja przeprowadzona w oparciu o łączne wyniki badań wykazała, że potwierdziło się siedem z ośmiu założonych hipotez.

Hipoteza nr 1 zakładająca, że stopień oddziaływania tradycyjnej kuchni na wzrost zainteresowania danym regionem zarówno przez potencjalnych turystów jak i lokalnych mieszkańców jest wysoki, w pełni potwierdziła się.

Hipoteza nr 2 zakładająca, że poziom zainteresowania kuchnią regionalną wśród mieszkańców województw: wielkopolskiego, pomorskiego i kujawsko-pomorskiego jest na średnim poziomie, nie potwierdziła się

Hipoteza nr 3 zakładająca, że wiedza na temat potraw staropolskich i regionalnych jest na średnim poziomie, potwierdziła się.

Hipoteza nr 4 zakładająca, że w świadomości społecznej, w stopniu umiarkowanym funkcjonuje pojęcie restauracji typu karczma oferującej regionalne jedzenie, potwierdziła się.

Hipoteza nr 5 zakładająca, że Krajna jako region kulturowy jest rozpoznawalna, potwierdziła się.

Hipoteza nr 6 zakładająca, że kuchnia regionalna jest atrakcyjna, potwierdziła się. Respondenci ocenili kuchnię regionalną jako szczególnie atrakcyjną.

Hipoteza nr 7 zakładająca, że atrakcyjność kuchni regionalnej może być czynnikiem decydującym o wyborze miejsca wypoczynku lub podróży w stopniu wysokim, potwierdziła się.

Hipoteza nr 8 zakładająca, że metody promocji produktów regionalnych są nie wystarczające, potwierdziła się.

Wnioski

W wyniku analizy przeprowadzonych badań zostały sformułowane następujące wnioski:

- Atrakcyjność potraw sporządzanych wg tradycyjnych receptur, z wykorzystaniem naturalnych składników pozytywnie wpływa na wybór miejsca wypoczynku bądź podróży.

- Regionalna tradycyjna kuchnia stanowi element wysoce atrakcyjny a jako taki może wpływać na rozwój turystyki kulturowej, a także turystyki w ogóle w badanym rejonie.

- Ważną rolę w zakresie upowszechnienia produktów tradycyjnych i kuchni regionalnej mają restauracje, karczmy lub oberże, które kultywują tradycję lokalną poprzez wystrój wnętrz i kuchnię regionalną.

- Kuchnia regionalna może być znakomitym uzupełnieniem innych produktów turystycznych, w szczególności związanych z dziedzictwem narodowym i kulturową turystyką lokalną.

\section{Wstęp}

Niniejsze opracowanie dotyczy wpływu walorów lokalnej kuchni tradycyjnej na rozwój turystyki. W tym ujęciu wskazany został region kulturowy Krajny, tzw. ziemi pogranicza. Podjęto się omówienia powyższego zagadnienia ze względu na potrzebę i jednocześnie obowiązek czerpania z dziedzictwa kulturowego, z pożytkiem dla rozwoju społeczeństwa. Przykładem takiego działania dającego impuls dla rozwoju turystyki może być wykorzystanie smaków i aromatów dawnej kuchni polskiej, jako atrakcji przyciągającej turystów. Uwzględniono przy tym ścisły związek codziennych rytuałów żywieniowych z folklorem polskiej wsi (Grosse 2002), (Rohrscheidt, 2008). Dodatkową korzyść stanowi wzrost zainteresowania zdrową żywnością, co ma niebagatelne znaczenie $\mathrm{w}$ dobie rozprzestrzeniania się żywności genetycznie modyfikowanej GMO, bogatej w szkodliwe azotany i azotyny oraz pierwiastki metali ciężkich, co może wiązać się ze zwiększonym ryzykiem zachorowań na metaboliczne schorzenia cywilizacyjne (Buczkowska 2008), (Mokras-Grabowska 2009.

Głównym zamierzeniem pracy jest zatem zbadanie stopnia oddziaływania tradycyjnej kuchni na wzrost zainteresowania danym regionem zarówno przez potencjalnych turystów jak i lokalnych mieszkańców. W celu poznania tego zjawiska posłużono się metodą sondażu diagnostycznego w postaci badań ankietowych. oraz wywiadu swobodnego.

W części początkowej pracy scharakteryzowano elementy polskiej kuchni tradycyjnej oraz regiony turystyczne Polski. Następnie przedstawiono region Krajny, która służy jako przykład w zobrazowaniu szans rozwojowych dla turystyki poprzez promowanie kultury.

W części empirycznej wykorzystano kwestionariusz ankiety jako narzędzie badawcze. Przy jego pomocy przebadano 117 osób pochodzących głównie z województw: Wielkopolskie, KujawskoPomorskie oraz Pomorskie. Głównym celem badania było uzyskanie odpowiedzi na pytanie, w jakim stopniu następuje oddziaływanie potraw tradycyjnej kuchni regionalnej na zainteresowanie turystyką regionu. 


\section{Charakterystyka kuchni staropolskiej}

Pojęcie kuchni tradycyjnej można łatwo wyjaśnić w oparciu o definicje pojęć kuchnia i tradycja. Tradycja, wg słownika języka polskiego (Dunaj, 2003) to przekazywane z pokolenia na pokolenie, historycznie ukształtowane obyczaje, poglądy, wierzenia, zasady postępowania, sposoby myślenia; zwyczaj.

Zgodnie z Encyklopedią PWN (Kalisiewicz, 1998) tradycja to przekazywane z pokolenia na pokolenie treści kulturowe (obyczaje, poglądy, wierzenia, sposoby myślenia i zachowania, normy postępowania itp.) uznane przez daną zbiorowość (naród, lud) za społecznie doniosłe dla jej współczesności i przyszłości oraz proces przekazywania tych treści kulturowych $\mathrm{w}$ danej zbiorowości. Jak widać obie treści są do siebie zbliżone, jednakowoż druga definicja obrazuje zagadnienie znacznie głębiej (Gaworecki, 2000).

Natomiast kuchnia wg ww. słownika to sztuka kulinarna, zestaw potraw, napojów i sposoby ich przyrządzania, charakterystyczne dla danego kraju, narodu, regionu itp., a staropolski to po prostu dotyczący dawnej Polski, dawnych Polaków; używany w dawnej Polsce. Podobnie staropolszczyzna oznacza zarówno język staropolski jak i kulturę i obyczaje staropolskie. Reasumując, polska kuchnia tradycyjna to nic innego jak dawna sztuka kulinarna przekazywana z pokolenia na pokolenie (Dombrowicz, Michniewicz-Ankiernsztajn, 2011), (Kruczek., Walas, 2009).

Natomiast kuchnia wg ww. słownika to sztuka kulinarna, zestaw potraw, napojów i sposoby ich przyrządzania, charakterystyczne dla danego kraju, narodu, regionu itp., a staropolski to po prostu dotyczący dawnej Polski, dawnych Polaków; używany w dawnej Polsce. Podobnie staropolszczyzna oznacza zarówno język staropolski jak i kulturę i obyczaje staropolskie. Reasumując, polska kuchnia tradycyjna to nic innego jak dawna sztuka kulinarna przekazywana z pokolenia na pokolenie. (Churski, 2004).

W początkowej fazie kształtowania się kuchni tradycyjnej w okresie średniowiecza potrawy były nieliczne i ubogie. Żywiono się głównie produktami zbożowymi, z których wypiekano placki, spożywano także kapustą, rośliny strączkowe, kasze z których przygotowywano krupniki. Jadano też żury i polewki. Mięso należało do luksusowych rarytasów, jadano je najczęściej z okazji obchodzenia świąt. W późniejszym czasie zamiast placków wypiekano już chleb, a w XV i XVI wieku. przywędrowały na ziemie polskie z Włoch nowe warzywa, które przyczyniły się do urozmaicenia pożywienia. W połowie XVIII wieku pojawiły się ziemniaki. Zmiany w polskiej kuchni zachodziły bezustannie, do czego przyczynił się rozwój handlu, wymiana międzyregionalna i rozwój gospodarczy. Najwięcej zmian nastąpiło w połowie XIX wieku, kiedy to po przemianach gospodarczych chłopi stali się bardziej zamożni. Zmiany te pozwoliły im na eksperymentowanie z zupełnie innymi potrawami, które dotychczas były dla nich obce (Kęcińska, 2007).

Dawna kuchnia polska charakteryzowała się starannym doborem rozmaitych przypraw wzbogacających smak potraw, których sposób podania, w domach szlacheckich był niezwykle wykwintny. Sztuka kulinarna w każdym z regionów Polski ukształtowała się nieco inaczej, zachowując przy tym wspólną podstawę. Występujące różnice powodowane były zazwyczaj wpływami krajów sąsiadujących, a także wywodzącymi się z krajów dalekich dzięki wędrującym handlarzom. Bywało też i tak, że swój początek w polskiej kuchni potrawa miała na królewskim dworze, bowiem panujący sprowadzali często zagranicznych kucharzy, aby zasmakować ,światowej kuchni”. Prawdopodobnie gdy dana potrawa lub przyprawa przypadła królowi do gustu, pojawiała się również na stołach magnackich i szlacheckich.

W kuchni polskiej bardzo ważną rolę odgrywały wszelkiego rodzaju mięsa: dziczyzna tj. mięso zajęcze, łosia i żubra, sarnina oraz wieprzowina, wołowina, cielęcina, mięso woła. Drób hodowano głownie w celu pozyskania pierza i jaj, niemniej jednak w rodzinach szlacheckich kurczak, gęś, kaczka, głuszec, kuropatwa, bażant, przepiórka - często gościły na biesiadnych i powszednich stołach. Natomiast w rodzinach chłopskich mięso spożywano głównie w trakcie świąt i uroczystości. Popularne były różnorodne gatunki ryb: łosoś, czeczuga, jesiotr, pstrąg, brzan, boleń, rap, śliz, kiełb, lipień, cert, węgorz, śledź, flądra, szczupak, karp, okoń, karaś, leszcz, lin, dorsz. (Snaglewska, Zahorska, 1989).

Jadano także kasze: z gryki łuszczonej i łamanej, kasze pszenne: manna, żytnia, jęczmienne(zwykłe i perłowe), owsiane, gryczaną i jaglane. Kasze odgrywały w żywieniu ważną rolę, stanowiły podstawę jadłospisu rodzin chłopskich zanim został on urozmaicony większą ilością warzyw. Znane wtedy warzywa to przede wszystkim: kapusta, kalafior, brokuł, karczoch, kard, szparag, burak, seler, sałata, szpinak, rzeżucha, szczaw, ogórki, pasternak, rzepa, rzodkiew, marchew, pietruszka, chrzan, cebula, czosnek, fasola, soczewica, 
jarmuż, karpiel, por, bób, dynia, pomidory, ziemniaki. Nabiał (jaja, ser, mleko) wówczas spożywano rzadko. Czasem wykorzystywano również mięczaki, skorupiaki - ostrygi, żółwie, raki, ślimaki.

Stosowano przyprawy obcego pochodzenia (imbir, pieprz, ziele angielskie, gałkę i kwiat muszkatołowy, cynamon, liście laurowe, goździki, paprykę, szafran) i polskie (pietruszka, majeranek, kminek, jałowiec, mięta, rozmaryn, tymianek, szałwia, lubczyk, czomber, czosnek, koper, suszone śliwki, miód, piwo). Ta różnorodność składników zależała od upraw; obecnie niektóre z powyżej wymienionych nie należą już do popularnych bądź są na nowo odkrywane.

Najstarsze znane w Polsce techniki obróbki termicznej mięs, ryb i drobiu to pieczenie, gotowanie i duszenie. Potrawy smażone pojawiły się w połowie XIX wieku. Sztuki mięsa podawane były z ćwikłą, chrzanem ze śmietaną i migdałami, ogórkami, musztardą, sosami z cebuli, czosnku, fasoli. Sporządzane z drobiu, dziczyzny i cielęciny potrawki (podprawiane 'gąszczem', żółtkami i śmietaną), czyli duszone w rosole kawałki mięsa z dodatkiem warzyw, owoców i przypraw podawano z kaszą krakowską, jęczmienną, polskim makaronem, grochem, szparagami i pierożkami z cielęcej nerki. Zraziki, nazywane suropiekami, przygotowywane były z wołowiny, szpikowane słoniną, a następnie duszone w rosole, przyprawiane rozmarynem, imbirem, cytryną, piwnym lub winnym octem, podawane z kaszą gryczaną, grzankami lub bulwami. Pieczono $z$ różnego rodzaju mięs pasztety. Bigosy - duszone lub zapiekane sporządzano z kwaszonej kapusty, kawałków różnych mięs, grzybów, korzeni i ziół. Znane były bigosiki - potrawy bardzo podobne do bigosów, z jednym tylko wyjątkiem, zamiast kapusty dodawano winne owoce.

Jeszcze w XIII wieku tylko zamożne klasy społeczne spożywały chleb. Ludzie biedniejsi w swych domostwach posiadali paleniska na których mogli przygotować jedynie podpłomyki, zaliczane do pieczywa prymitywnego. W późniejszym czasie białe pieczywo przeznaczone było dla dworzan a razowe dla ludzi uboższych. Długo nie było w Polsce wina, jego funkcję pełniły miody pitne (półtorak, dwójniak, trójniak) o odpowiedniej zawartości alkoholu, wyrabiane z miodu pszczelego, dziś uznane za część polskiego dziedzictwa kulinarnego. Natomiast piwo, prawdopodobnie najstarszy napój alkoholowy, początkowo produkowane na bazie słodu jeczmiennego, a potem także chmielu, najczęściej miodowe lub z jałowca. Do serwowania $\mathrm{i}$ spożywania potraw używano głównie glinianych naczyń.

Obecnie często zapomina się o bogatej ofercie staropolskich produktów, przypraw i sposobach sporządzania posiłków, sięgając po przyprawy typowe dla kuchni zupełnie innych regionów świata. Gospodyni domowa na miarę XXI wieku wytrwale podąża za kulinarnymi trendami i chętnie wykorzystuje przepisy z kuchni orientalnej lub śródziemnomorskiej (Dzikowska, 2006).

\section{Zarys specyfiki kuchni regionalnej - Krajna}

Krajna to obszar pograniczny między Wielkopolską i Kaszubami, zaliczany bądź do Wielkopolski północnej, bądź do Pomorza. Geografia regionalna za naturalną granicę pomiędzy Wielkopolską a Pomorzem uznaje bagna nadnoteckie (Gajek, 2009). Od północy Krajna graniczy z Kaszubami, od wschodu z Borami Tucholskimi, a od południa z Pałukami. Zawarta jest między rzekami Debrzynką i Kamionką (od północy), Notecią (od południa), Gwdą (od zachodu) i Brdą (od wschodu). Pod względem administracyjnym, należy do trzech województw: kujawskopomorskiego (Kamień Krajeński, Sępólno Krajeńskie, Więcbork, Nakło nad Notecią), pomorskiego i wielkopolskiego (Złotów). Na Krajnie nie ma większych miast. Do największych i najważniejszych miejscowości należą: Nakło nad Notecią historyczna stolica Krajny, Złotów, Sępólno Krajeńskie, Więcbork, Wyrzysk (Kondracki, 2009), (Rohrscheidt 2008), (Lijewski, Mikułowski 2008).

Leżąca na styku kilku w województw Krajna posiada niezwykle bogaty wybór potraw kuchni regionalnej, spowodowany przenikaniem wpływów sąsiednich regionów tj. Wielkopolski, Pałuk czy Kaszub (Gotowt-Jeziorska, 1999). Te wzajemne oddziaływania przesądziły nie tylko o składnikach i smaku potraw ale także o ich nazwach. Zapożyczenia z Wielkopolski ( z wpływami niemieckimi) widoczne są w takich nazwach jak: pyra (ziemniak), szneka (drożdżówka), sznytki (kromki chleba). Podstawowym składnikiem dawnej kuchni regionalnej Krajny były kasze i polewki mączne, jednak tylko początkowo, jeszcze zanim pojawił się ziemniak, który stał się niezwykle popularny. Ziemniaki miały bardzo wiele zastosowań, gotowano je w mundurkach i podawano z solą, z kapustą, sporządzano z nich zupy (np. zupę ślepe ryby), dodawano do pieczenia chleba, gotowano szare kluski, smażono plendze, czyli placki ziemniaczane, które podawano $\mathrm{z}$ cebulką bądź cukrem. Placek pieczony z ziemniaków nosił nazwę bambrzok (Woźniak, 2009). 
W wieku XIX upowszechniło się spożycie chleba, zaczęto wypiekać go w piecach chlebowych znajdujących się w domach bądź poza nimi. Do krojenia chleba używano osobnego noża. Szczególne znaczenia miała jakość użytej do wypieków mąki, najczęściej używano mąki żytniej - rżanej. Z takiej mąki przygotowywano też zupy (nawarki, smelki, żury, polewki). Nawarka - war, czyli wrząca woda, dodawano do niej mąkę i mieszano drewnianą łyżką, zalewano mlekiem, czasami kraszono słoniną, olejem lub smalcem (Braun, 1998). Smelka - zupa sporządzana z podsmażonej z mąką kiełbasy i słoniny. Polewka - sporządzana z wody zagęszczonej mąką z maślanką, kwaśnym mlekiem lub śmietaną, dodawano do niej ziemniaki lub chleb. Żur nazywany barszczem, gotowany na zakwasie z mąki żytniej, podawany z kiełbasą, ziemniakami, kraszony słoniną lub boczkiem wędzonym (Tazbir, 1983).

Mięso, w bogatszych domach pojawiało się na stołach trzy razy w tygodniu. Królowała wieprzowina, baranina, drób i mięso kóz. Początkowo z mięsa jagnięcego, później z drobiu sporządzano rosót, czernine przyrządzano z krwi kaczej, mąki i przypraw. W XIX wieku ogólno dostępne stały się takie potrawy jak: smażonka wieprzowa, golonka peklowana z grochem, schab pieczony, gęś lub kaczka pieczona. Na zimno spożywano galat, nazywany też trzęsionka lub zimnymi nóżkami. Do thustych mięs i sosów podawano gotowane na parze drożdżowe pyzy (Niedźwiedzk, 1980).

Ryby odgrywały dużą rolę w żywieniu tam, gdzie znajdowały się rzeki i jeziora. Przyrządzano je na wiele sposobów, marynowano, smażono, suszono, tak przygotowane

podawano do ziemniaków lub chleba. Smażone śledzie tzw. zielone śledzie, układano w zalewie octowej z cebulą i liśćmi bobkowymi, były one często piątkowym, postnym obiadem. Z ryb sporządzano także zupy, należał do nich kwas z ryb, gotowany z kwasem z kiszonej kapusty, grzybami i owocami (Rekowska, 2003).

Mleko, początkowo używane jako przedmiot handlu, w połowie XX wieku mleko i jego przetwory spożywane były na co dzień. Mleko traktowano jako napój, dodawano do zup, sosów, wyrabiano z niego twaróg i masło. Twaróg czyli biały ser podawano na słodko ze śmietaną, $\mathrm{z}$ cukrem, dżemem, lub na słono - gzik ze sznytlochem czyli z cebulą bądź też szczypiorkiem (Markuza-Bieniecka, Dekowski, 1976).

Dawniej na co dzień, a także w celach leczniczych parzono herbaty tzw. ziołowe: rumianek, kwiat lipy, koper, kwiat czarnego bzu zwany chybką. Spożywano także kawę zbożową, paloną z ziaren jęczmienia, żyta i pszenicy, podawaną na zimno z mlekiem oraz alkohole - najpierw piwo i miody pitne, potem wina owocowe, zbożowe, z głogu lub chabrów i wódkę.

Po dziś dzień na Krajeńskich stołach króluje biały barszcz - żur, polewki, rosół, gzik - podawany do ziemniaków i białego pieczywa, pyzy na parze, różnorodne mięsne zupy, pieczenie mięsne, potrawy ziemniaczane (Ogrodowiska, 2009), (Stasiak 2009).

\section{Cel pracy}

Celem przeprowadzanych badań jest określenie wpływu kulturowo-etnicznych walorów regionu (kuchnia regionalna) na rozwijanie się funkcji turystycznej $\mathrm{w}$ danym regionie na przykładzie Krajny. Obszar wybrany został z uwagi na zainteresowanie tematyką propagowania elementów kultury ludowej oraz możliwości realizacji tematu w tym posiadane kompetencje, czas i środki techniczne. Nie bez znaczenia są też własne doświadczenia współautorki, która początkowo była odbiorcą przekazu sztuki ludowej, a następnie także jej animatorem.

\section{Problemy i hipotezy badawcze}

Problem badawczy według ( Frakfort'a-Nachmias'a, 2001) to bodziec intelektualny wywołujący reakcję w postaci badań naukowych. Problem badawczy może być ustanowiony jako zdanie twierdzące lub pytające, a samo sformułowanie problemu polega na określeniu pytania, na które albo jeszcze nie ma odpowiedzi, albo nie jest ona dostatecznie precyzyjna. Jest formułowany za pomocą określonych pojęć, które odzwierciedlają zjawiska empiryczne. Hipoteza badawcza jest to wstępna odpowiedz na postawiony problem, dająca się sprawdzić empirycznie (należy ją zweryfikować w toku badań). W niniejszej pracy wyodrębniono następujące problemy badawcze oraz hipotezy:

\section{Problem glówny}

Jaki jest stopień oddziaływania tradycyjnej kuchni na wzrost zainteresowania danym regionem zarówno przez potencjalnych turystów jak i lokalnych mieszkańców? 


\section{Problemy szczegółowe}

Jaki jest poziom zainteresowania kuchnią regionalną wśród mieszkańców województw: głównie wielkopolskiego, pomorskiego i kujawsko-pomorskiego (ze względu na przynależność administracyjną Krajny)?

Jaka jest wiedza na temat potraw staropolskich i regionalnych?

Czy w świadomości społecznej funkcjonuje pojęcie restauracji typu karczma oferującej regionalne jedzenie?

Czy Krajna jako region kulturowy jest rozpoznawalna?

Czy kuchnia regionalna jest atrakcyjna?

Czy atrakcyjność kuchni regionalnej może być czynnikiem decydującym o wyborze miejsca wypoczynku lub podróży?

Czy metody promocji produktów regionalnych są wystarczające?

\section{Hipoteza główna:}

Zakłada się, że stopień oddziaływania tradycyjnej kuchni na wzrost zainteresowania danym regionem zarówno przez potencjalnych turystów jak i lokalnych mieszkańców jest wysoki.

\section{Hipotezy szczególowe:}

Zakłada się, że poziom zainteresowania kuchnią regionalną wśród mieszkańców województw: wielkopolskiego, pomorskiego i kujawsko-pomorskiego (ze względu na przynależność administracyjną Krajny) jest na średnim poziomie.

Zakłada się, że wiedza na temat potraw staropolskich i regionalnych jest na średnim poziomie.

Zakłada się, że w świadomości społecznej, w stopniu umiarkowanym funkcjonuje pojęcie restauracji typu karczma oferującej regionalne jedzenie.

Zakłada się, że Krajna jako region kulturowy jest rozpoznawalna.

Zakłada się, że kuchnia regionalna jest atrakcyjna.

Zakłada się, że atrakcyjność kuchni regionalnej może być czynnikiem decydującym o wyborze miejsca wypoczynku lub podróży w stopniu wysokim.

Zakłada się, że metody promocji produktów regionalnych są niewystarczające.

\section{Zmienne}

Zgodnie z teorią (Frakfort'a-Nachmias'a, 2001) zmienna to właściwość empiryczna mająca dwie lub więcej wartości (zmienna zależna to objaśniana, a niezależna objaśniająca). Ponadto jak podkreśla (Nowak, 1985) zmienna określa jedynie, pod jakim względem interesują nas analizowane przedmioty i zjawiska, specyfikując ich możliwe własności, stany lub zdarzenia, którym podlegają, a ponadto jakie typy relacji będziemy uwzględniać między przedmiotami rozpatrywanymi pod danym względem. Najczęściej dzielimy je na zmienne zależne i niezależne.

Wskaźnik badawczy to pewna charakterystyczna cecha, zdarzenie lub zjawisko na podstawie zajścia $\mathrm{z}$ którego wnioskujemy $\mathrm{z}$ pewnością lub $\mathrm{z}$ prawdopodobieństwem wyższym od przeciętnego, iż zachodzi zjawisko, które nas interesuje.

Tabela 1. 0 Wyszczególnienie zmiennych oraz wskaźników

\begin{tabular}{|c|c|c|}
\hline zmienna niezależna & zmienna zależna & \\
\hline \multirow[b]{2}{*}{ wiek } & poziom wiedzy nt. kuchni tradycyjnej & \\
\hline & poziom zainteresowania kuchnią tradycyjną & \\
\hline \multirow{3}{*}{ wykształcenie } & wzrost zainteresowania kuchnią tradycyjną & \\
\hline & poziom świadomości regionalnej & \\
\hline & wybór kuchni tradycyjnej jako czynnika & \\
\hline \multirow{3}{*}{ miejsce zamieszkania } & determinującego miejsce wypoczynku & \\
\hline & poziom promocji produktu & \\
\hline & stopień zainteresowania produktem & \\
\hline województwo & ocena walorów smakowych potraw & \\
\hline
\end{tabular}

Źródło: opracowanie własne 


\section{Metody, techniki i narzędzia pomiaru}

Zastosowane metody badawcze $\mathrm{w}$ niniejszym opracowaniu to: sondaż diagnostyczny, a jako główną technikę przyjęto badania ankietowe, kwestionariusz ankiety składający się z 6 pytań, w większości zamkniętych, został wypełniony online przez próbę 117 respondentów. Badania miały zmierzyć poziom wiedzy o potrawach regionalnych oraz zainteresowania Krajną jako regionem kulturowym. $Z$ uwagi na wysoką ocenę atrakcyjności potraw tradycyjnych kuchni regionalnej, postanowiono potwierdzić dany punkt badań ankietowych przy pomocy technik wspierających proces badawczy, jakimi są obserwacja oraz wywiad swobodny-terenowy. Obserwacje i wywiad swobodny- terenowy, który stanowiły poniekąd badanie opinii konsumentów, przeprowadzono na próbie 52 osób, zadbano o to aby próba ta reprezentowała osoby w różnym wieku zamieszkujące na wsi i w mieście.

\section{Charakterystyka badanej grupy/próby}

Badania sondażowe zostały przeprowadzone na próbie 117 osób z doboru losowego prostego, w przedziale wiekowym 19-30 lat. Ludzie ci są mieszkańcami województw: wielkopolskiego, pomorskiego, kujawsko-pomorskiego. Badani respondenci pochodzili zarówno z obszarów wiejskich jak i miejskich.

Poniższe ryciny przedstawiają rozkład badanej próby według wieku, wykształcenia oraz miejsce zamieszkania.

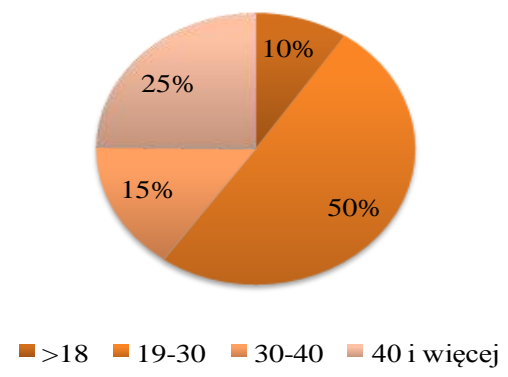

Ryc. 1. Struktura badanej próby (populacji) według wieku.

Źródło: opracowanie własne.

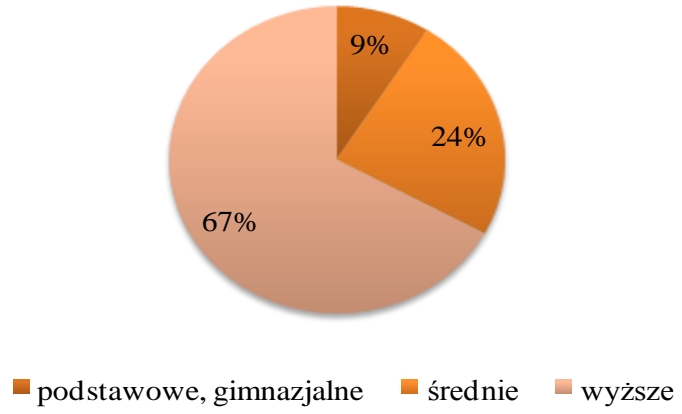

Ryc. 2. Struktura badanej próby (populacji) według wykształcenia.

Źródło: opracowanie własne.

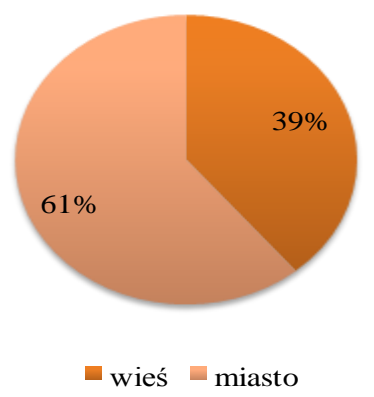

Ryc. 3. Struktura badanej próby (populacji) według miejsca zamieszkania.

Źródło: opracowanie własne. 


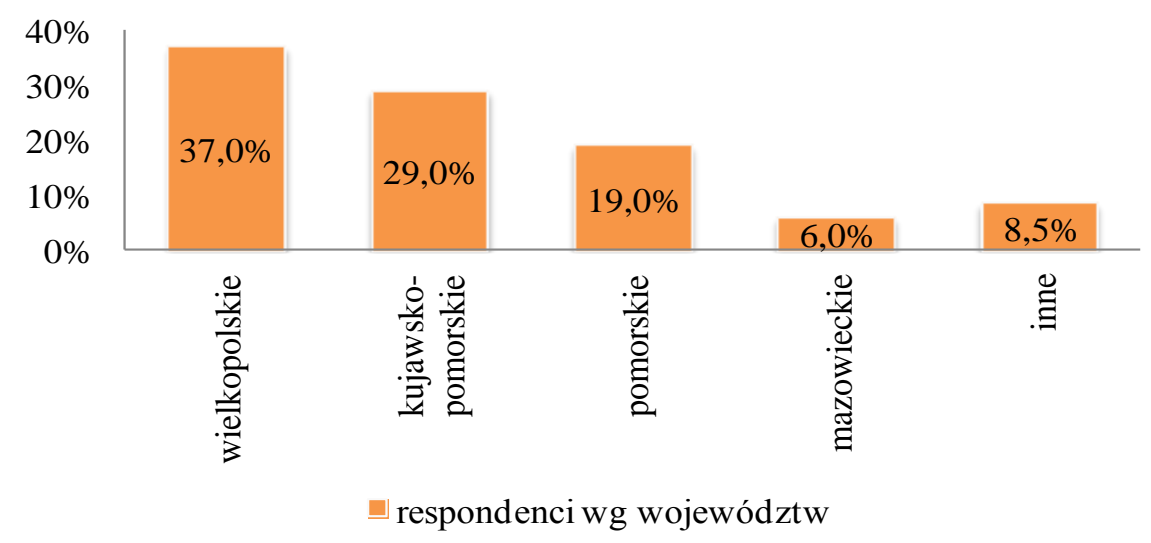

Ryc. 4. Struktura badanej próby (populacji) według miejsca zamieszkania z uwagi na województwo.

Źródło: opracowanie własne.

Przeważającą grupę respondentów stanowią kolejno mieszkańcy Wielkopolski (37\%), następnie województwa kujawsko-pomorskiego (29\%) oraz pomorskiego (19\%).Próba badawcza stanowi więc grupę głównie o wykształceniu wyższym (67\%), w przedziale wiekowym od 19 do 30 roku życia (50\%), głównie pochodzących z obszarów miejskich (61\%), mieszkańców województw do których administracyjnie przynależy Krajna i okolice.

\section{Znajomość specyfiki żywieniowej obszaru Krajna}

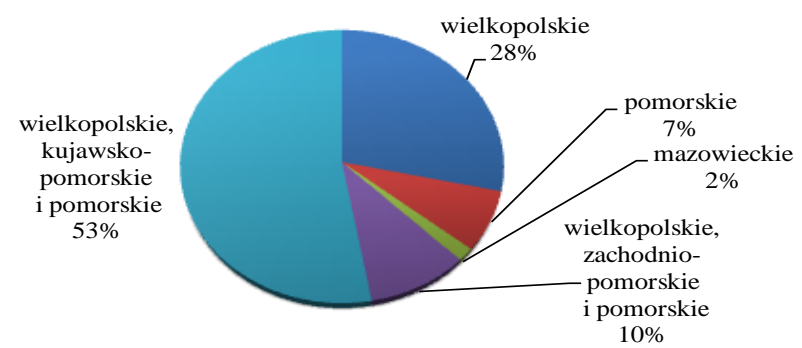

Ryc. 5. Przynależność administracyjna obecnej Krajny wg respondentów

Źródło: opracowanie własne

Najwięcej, bo $53 \%$ badanych prawidłowo określiło położenie administracyjne Krajny. $28 \%$ wskazało na płożenie w obrębie samej tylko Wielkopolski być może kierując się granicami historycznymi sprzed okresu rozbiorów. Przedstawione wyniki świadczą o tym, iż respondenci w większości znają położenie Krajny lecz w wielu przypadkach źle ją lokalizują administracyjnie.

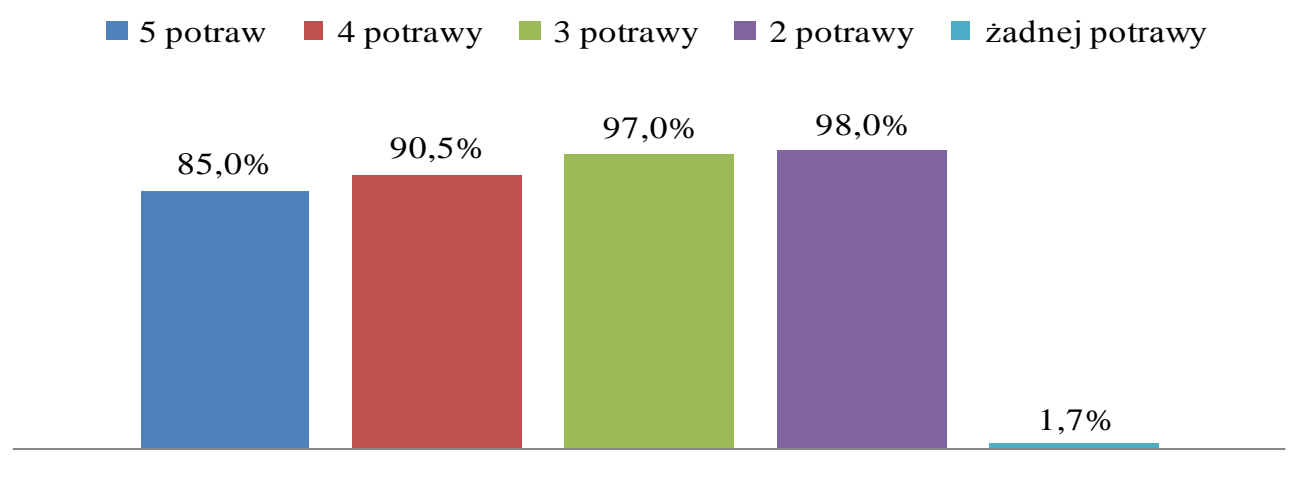

znajomość potraw kuchni staropolskiej wśród respondentów (oczekiwana liczba: 5)

Ryc. 6. Znajomość potraw tradycyjnych wśród respondentów

Źródło: opracowanie własne 
Spośród pięciu możliwych do wymienienia potraw, wszystkie 5 wymieniło $85 \%$ respondentów. 4 potrawy potrafiło wskazać około $90 \%$ respondentów, natomiast 3 potrawy $97 \%$. 98\% badanych wskazało tylko 2 potrawy. Wyniki świadczą poziomie świadomości pochodzenia potraw.

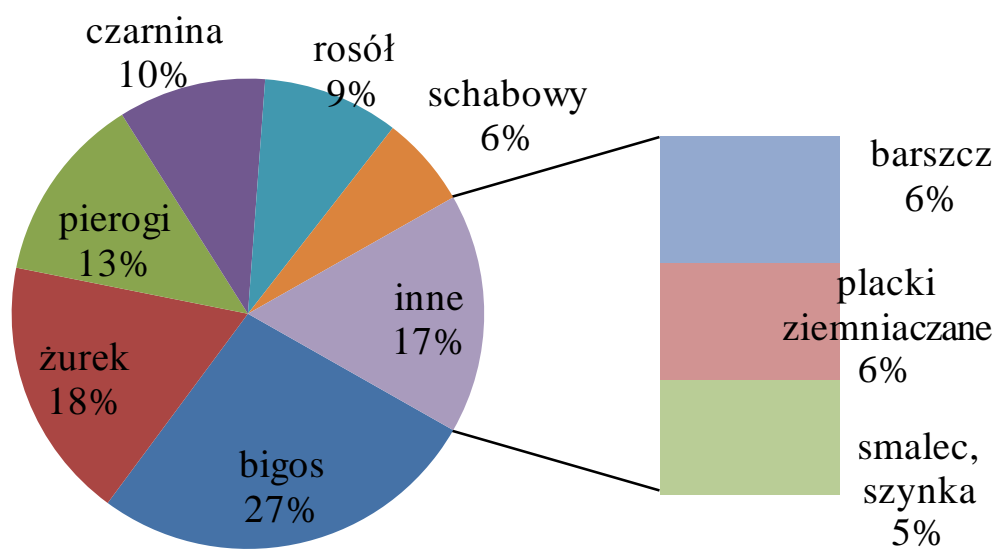

Ryc. 7. Częstość wymienianych przez respondentów potraw kuchni staropolskiej.

Źródło: opracowanie własne.

Powyższa rycina wskazuje na to, iż najbardziej znaną potrawą staropolską jest bigos, $27 \%$ wszystkich wskazanych potraw, następnie żurek (18\%), pierogi (13\%), czarnina(10\%) i rosół(9\%). Czyli potrawy sporządzane $\mathrm{z}$ okazji świąt, prawdopodobnie dlatego też najsilniej utrwaliły sie w tożsamości społeczeństwa jako tradycyjne.

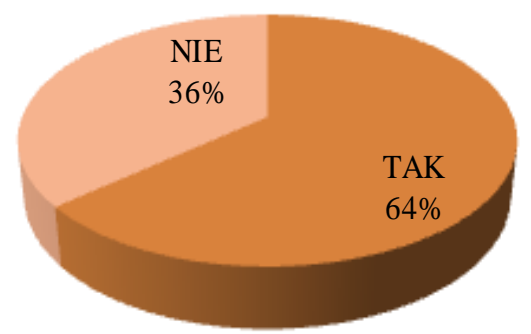

Ryc. 8. Znajomość restauracji typu karczma.

Źródło: opracowanie własne.

Więcej niż połowa badanych tj. 64\%, ma świadomość istnienia karczm regionalnych. Tylko 7\% badanych twierdzi, iż promocja produktów regionalnych jest wystarczająca (Ryc. 9) i aż 34\% uważa ją za nie wystarczającą. Ponadto duży odsetek respondentów (36\%) uważa, iż należy podjąć w tym zakresie dodatkowe działania. Prawie 13\% twierdzi, że produkty w ogóle nie są promowane, a $9,5 \%$ nie posiada żadnej wiedzy na ten temat.

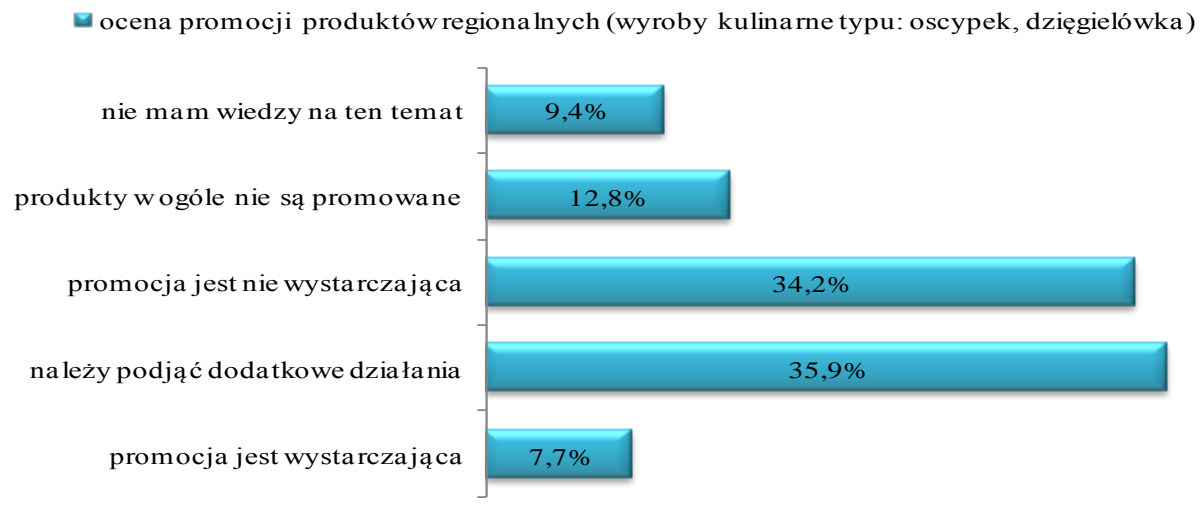

Ryc. 9. Ocena promocji produktów regionalnych.

Źródło: opracowanie własne. 
Dodatkowo respondenci oceniali stopień wpływu potraw regionalnych na zainteresowanie regionem w skali od 1 do 10 . Respondenci ocenili wpływ potraw kuchni regionalnej na zainteresowanie regionem w stopniu średnio wysokim. Średnia przyznanych punktów wyniosła $7,1 \pm 1,0$ pkt. (Tabela 2 ).

Tabela 2.Stopień wpływu potraw regionalnych na zainteresowanie regionem w skali od 1 do 10 .

\begin{tabular}{|c|c|}
\hline kategoria & średnia punktów \\
\hline $\begin{array}{lcc}\text { stopień } & \text { wpływu } & \text { potraw } \\
\text { na zainteresowanie regionem } & \end{array}$ & $7,1 \pm 1,0$ \\
\hline
\end{tabular}

Źródło: opracowanie własne.

Tabela 3. Determinanty wyboru miejsca wypoczynku/podróży.

\begin{tabular}{|l|l|}
\hline kategoria & atrakcyjność w \% \\
\hline luksusowa baza hotelowa & $47 \%$ \\
\hline walory przyrodnicze i krajoznawcze & $91 \%$ \\
\hline $\begin{array}{l}\text { możliwość zapoznania się z lokalnym folklorem } \\
\text { (obrzędy, tańce, gwara, rzemiosło ludowe) }\end{array}$ & $77 \%$ \\
\hline $\begin{array}{l}\text { potrawy tradycyjnej kolskiej } \\
\text { (wykonane wg starych domowych receptur np. domowy } \\
\text { chleb } \\
\text { na zakwasie, ciasto drożdżowe, miód pitny) }\end{array}$ & $80 \%$ \\
\hline żywność typu fast food & $27 \%$ \\
\hline
\end{tabular}

Źródło: opracowanie własne.

Najwyższą atrakcyjnością wśród respondentów odznaczają się następujące determinanty: walory przyrodnicze i krajoznawcze (91\%), a następnie potrawy tradycyjnej polskiej kuchni $(80 \%)$ oraz chęć zapoznania się z folklorem (77\%). Nisko oceniono luksusową bazę hotelową, jako czynnik decydujący o wyborze miejsca wypoczynku (47\%), a także dostępność pożywienia typu fast food $(27 \%)$.

\section{Weryfikacja hipotez}

Weryfikacja przeprowadzona w oparciu o łączne wyniki badań wykazała, że potwierdziło się siedem z ośmiu założonych hipotez.

Hipoteza nr 1 zakładająca, że stopień oddziaływania tradycyjnej kuchni na wzrost zainteresowania danym regionem zarówno przez potencjalnych turystów jak i lokalnych mieszkańców jest wysoki, w pełni potwierdziła się.

Hipoteza nr 2 zakładająca, że poziom zainteresowania kuchnią regionalną wśród mieszkańców województw: wielkopolskiego, pomorskiego i kujawsko-pomorskiego jest na średnim poziomie, nie potwierdziła się

Hipoteza nr 3 zakładająca, że wiedza na temat potraw staropolskich i regionalnych jest na średnim poziomie, potwierdziła się.

Hipoteza nr 4 zakładająca, że w świadomości społecznej, w stopniu umiarkowanym funkcjonuje pojęcie restauracji typu karczma oferującej regionalne jedzenie, potwierdziła się. się.

Hipoteza nr 5 zakładająca, że Krajna jako region kulturowy jest rozpoznawalna, potwierdziła 
Hipoteza nr 6 zakładająca, że kuchnia regionalna jest atrakcyjna, potwierdziła się. Respondenci ocenili kuchnię regionalną jako szczególnie atrakcyjną.

Hipoteza nr 7 zakładająca, że atrakcyjność kuchni regionalnej może być czynnikiem decydującym o wyborze miejsca wypoczynku lub podróży w stopniu wysokim, potwierdziła się.

Hipoteza nr 8 zakładająca, że metody promocji produktów regionalnych są nie wystarczające, potwierdziła się.

\section{Wnioski}

W wyniku analizy przeprowadzonych badań zostały sformułowane następujące wnioski:

1. Atrakcyjność potraw sporządzanych wg tradycyjnych receptur, z wykorzystaniem naturalnych składników pozytywnie wpływa na wybór miejsca wypoczynku bądź podróży.

2. Regionalna tradycyjna kuchnia stanowi element wysoce atrakcyjny a jako taki może wpływać na rozwój turystyki kulturowej, a także turystyki w ogóle w badanym rejonie.

3. Ważną rolę w zakresie upowszechnienia produktów tradycyjnych i kuchni regionalnej mają restauracje, karczmy lub oberże, które kultywują tradycję lokalną poprzez wystrój wnętrz i kuchnię regionalną.

4. Kuchnia regionalna może być znakomitym uzupełnieniem innych produktów turystycznych, w szczególności związanych z dziedzictwem narodowym i kulturową turystyką lokalną.

\section{Literatura}

1. Braun K. (red.): Zapisane w pamięci. Opowieści o kulturze ludowej. Wyd. Didasko, Warszawa 1998.

2. Buczkowska K.: Turystyka kulturowa: przewodnik metodyczny. Akademia Wychowania Fizycznego im. Eugeniusza Piaseckiego w Poznaniu, Poznań 2008.

3. Churski P.: Rozwój regionalny i lokalny w warunkach transformacji gospodarczej i integracji europejskiej. Instytut Geografii i Rozwoju Regionalnego, Uniwersytet Wrocławski, Wrocław 2004.

4. Dombrowicz M., Michniewicz-Ankiernsztajn H., Turystyka w rozwoju regionalnym i lokalnym Krajny i Pałuk. Promotio Geographica Bydgostiensia. Wyd. UKW, Bydgoszcz 2011.

5. Dunaj B. (red.): Domowy popularny słownik języka polskiego. Wyd. Wilga, Warszawa, 2003.

6. Dzikowska E.: Groch i kapusta, czyli podróżuj po Polsce. Wyd. Rosikon Press, Warszawa 2006.

7. Frakfort-Nachmias Ch., Nachmias D.: Metody badawcze w naukach społecznych. Wyd. Zysk i S-ka, Poznań 2001.

8. Gajek J.: Struktura etniczna i kultura ludowa Pomorza. Wyd. Bernardinum, GdańskWejherowo 2009.

9. Gaworecki W.: Turystyka. PWE, Warszawa 2000. 
10. Gotowt-Jeziorska A.: Gospodarka Turystyczna w regionach. Wyd. PST, 1999.

11. Grosse T. G.: Studia Regionalne i Lokalne: Przegląd koncepcji teoretycznych rozwoju regionalnego. Uniwersytet Warszawski, nr 1, 2002.

12. Kalisiewicz D. (red.): Encyklopedia popularna PWN. Wyd. Naukowe PWN SA, Warszawa 1998.

13. Kęcińska J.: Gdzie Stołunia falą błękitną lśni. Wyd. Leszczyńscy S.C., Wielki BuczekGdańsk 2007.

14. Kondracki J.: Geografia regionalna Polski. Wydawnictwo Naukowe PWN, Warszawa 2009.

15. KruczekZ., Walas B.: Nowoczesne postrzeganie promocji kulturowych produktów turystycznych, w: Stasiak A. (red.): Kultura i turystyka. Wspólnie zyskać. Wyd. WSTiH, Łódz 2009.

16. Lijewski T., Mikułowski B., Wyrzykowski J.: Geografia turystyki Polski. Wyd. PWE, Warszawa 2008.

17. Markuza-Bieniecka B., Dekowski J. P.: Kuchnia regionalna wczoraj i dziś. Wyd. Watra, Warszawa 1976.

18. Mokras-Grabowska J.: Możliwości rozwoju turystyki kulturowej obszarów wiejskich w Polsce. WSTiH, Łódź 2009.

19. Niedźwiedzki J.: Sztuka ludowa Krajny i Pałuk. Krajowa Agencja Wydawnicza, Poznań 1980.

20. Nowak S.: Metodologia badań społecznych. Wyd. naukowe PWN, Warszawa, 1985

21. Ogrodowiska B.: Polskie obrzędy i zwyczaje doroczne. Wyd. Sport i Turystyka, MUZA SA, Warszawa 2009.

22. Rohrscheidt A. M: Turystyka kulturowa: fenomen, potencjał, perspektywy. GWSHM, Gniezno 2008.

23. Rohrscheidt A. M.: Kulturowe szlaki turystyczne- próba klasyfikacji oraz postulaty w zakresie ich tworzenia i funkcjonowania. GWSHM, Gniezno 2008.

24. Rekowska J.: Potrawy regionalne Północnej Wielkopolski. Wyd. WODR, Stara Łubianka 2003.

25. Stasiak A. (red): Kultura i turystyka - wspólnie zyskać. Wyd. WWSTiH, Łódz 2009.

26. Snaglewska B., Zahorska I.: Potrawy Staropolskie i regionalne. Wyd.CZRS, Warszawa 1989.

27. Tazbir J.: Kultura szlachecka w Polsce. Rozkwit-Upadek-Relikty.Wyd. Omega, Warszawa 1983.

28. Woźniak B. (red.): Regionalna kuchnia polska. Wyd. Olimp Media, Poznań 2009. 